\title{
Notes
}

\section{Choosing Representatives by Lottery Voting}

Current electoral systems, though purporting to count votes equally, in fact create legislatures that fail to represent the whole community. This Note presents a thought experiment inviting the reader to consider seriously an alternative method of selecting representatives to legislatures that combines features of four traditional egalitarian systems: voting, lottery, quota, and rotation. Under "lottery voting," citizens would vote for representatives in local districts, much as they do today. Rather than automatically electing the candidate who receives a majority or plurality of votes, however, lottery voting chooses the winner in a lottery of the ballots cast: A single ballot is randomly drawn, and the candidate chosen on that ballot wins the election. ${ }^{1}$ If $A$ receives sixty percent of the overall vote and $B$ gets forty percent, A does not automatically win; rather, A's ex ante chances of winning are sixty percent and B's are forty percent. ${ }^{2}$

Section I of the Note examines the puzzle of minority participation in a majoritarian political system and suggests that justice for minorities may require a new method of selecting legislatures; Section II discusses the American jury and other historical uses of political lotteries; Section III sketches the implications of lottery voting and demonstrates how it could be used to create a richer democracy; and Section IV surveys the practical and constitutional limitations on lottery voting as a mechanism of social choice. The ideas presented furnish a novel perspective on various problems of democratic and constitutional theory.

1. Although lottery voting might be used in a multi-member district, this Note for simplicity assumes use in a single-member district. But see infra note 103 (suspending assumption).

2. Bruce Ackerman and Robert Paul Wolff have briefly suggested prototypes of lottery voting. See B. Ackerman, Social Justice in the Liberal State 285-89 (1980); R. Wolff, In Defense of ANARCHISM 44-48 (1970). Although both touch on lottery voting as a way to decide issues, lottery voting is workable only as a method of selecting representatives, who will in turn make ultimate policy decisions, see infra p. 1303. Neither Wolff nor Ackerman offers extensive discussion or analysis of the implications of lottery voting, but Ackerman concludes by "leav[ing] question[s] hanging in the air" and inviting others to devote more serious thought to lottery voting. B. ACKERMAN, supra, at 289. This Note takes up that invitation. 


\section{The Problem of Discrete and Insular Minorities}

The plight of discrete and insular minorities-paradigmatically, the poor and the black ${ }^{3}$ - who are systematically denied free access to the bazaar of pluralist politics poses a vexing problem in American democratic and constitutional theory. When democratic pluralism breaks down, legislatures, and thus acts of legislation, lose their presumptive legitimacy. ${ }^{4}$ Scholars have typically offered two solutions to ensure justice for minorities, but both are problematic.

First, many have invoked footnote four of Carolene Products in support of judicial review to remedy the structural imperfections of the legislative marketplace. ${ }^{5}$ Unfortunately, judges cannot vindicate minority rights simply by protecting the right to vote. Policing against malapportionment and franchise restrictions is insufficient because "those with most of the votes are in a position to vote themselves advantages at the expense of the others, or otherwise refuse to take their interests into account. "'One person, one vote under these circumstances, makes a travesty of the equality principle." "\# And despite assertions of the procedural nature of footnote-

3. For convenience, this Note will regularly use examples involving blacks to illustrate how the prevalent method of selecting legislators disadvantages discrete minority groups in ways that other imaginable voting systems-cumulative voting and lottery voting, for example-would not. It should be noted at the outset, however, that the latter two systems would benefit not simply those demographic groups traditionally viewed as discrete and insular, but also ideological minorities that, precisely because they transcend traditional notions of "class" and "group" based on demography, have rarely been viewed as paradigmatic "victims" of majoritarianism. Libertarians and socialists, for example, are rarely catalogued as discrete and insular minorities, yet they too have been systematically denied fair representation in legislatures governed by current electoral rules, and would benefit from lottery voting or cumulative voting. See infra notes 61,64, pp. 1296-97. Indeed, part of the appeal of these two voting systems is that they reduce the need to rely on judges to define which minorities are "discrete and insular" enough to warrant special solicitude. See infra p. 1285.

4. Where true pluralism prevails, the principle of majority rule enjoys singular appeal as the "fair" and "democratic" process for resolving political disputes. Because legislatures are more sensitive than courts to majoritarian impulses, it is often argued that courts should ordinarily defer to legislatures unless some structural imperfection in the political marketplace exists, such as discrimination against discrete and insular minorities. See J. ELY, DEMOCRACY AND DisTrust (1980).

Part of the appeal of the majority-rule principle lies in its guarantee that, on any given issue, there will be more winners than losers. In the absence of real pluralism, however, this justification for majoritarianism and legislative supremacy rings hollow. If certain groups almost always find themselves on the losing end of important votes, then majoritarianism may mask a tyranny that consistently rewards some citizens by oppressing others. The promise of pluralism is that the cumulative benefits of majoritarianism-that there will be more winners than losers-should redound to all relevant groups in society as they form cross-cutting alliances on different issues. By coalition-building and horse-trading, each group has the chance to win on the issues most important to it by making concessions on less important issues.

5. See United States v. Carolene Products Co., 304 U.S. 144, 152 n.4 (1938) ("statutes directed at particular religious . . . national . . . or racial minorities" or reflecting "prejudice against discrete and insular minorities" may tend "seriously to curtail the operation of those political processes ordinarily to be relied upon to protect minorities, and . . . may call for a correspondingly more searching judicial inquiry"); J. ELy, supra note 4 (offering a "process-oriented" footnote-four theory of judicial review); L. LUSKY, BY WHAT RIGHT? 12, 108-12 (1975) (integrating footnote four into author's theory of "implied judicial power").

6. J. Ely, supra note 4, at 135 (quoting J. Pennock, Democratic Political Theory 8-9 
four jurisprudence, ${ }^{7}$ Carolene Products judges who go beyond merely "clearing the channels of political change"s invariably confront knotty substantive questions ${ }^{9}$ and must make substantive value choices. These judges are not directly accountable to the electorate ${ }^{\mathbf{1 0}}$; nor is there any guarantee that they will be personally more representative of discrete and insular minorities than legislators. ${ }^{11}$ To make matters worse, judges receive information only in a passive and cramped way: Under Carolene Products, justice is blindered. ${ }^{12}$

A second typical solution, epitomized by Brown v. Board of Education $^{13}$ and the civil rights legislation of the 1960 's, ${ }^{14}$ is to assimilate minorities into the mainstream of American society so that they shed their discreteness and insularity. But mandatory integration-whether of neigh-

(1979)).

7. See J. Ely, supra note 4, at 102-03.

8. Id. at 105. Examples of such procedural "channel cleanings" include Harper v. Virginia Bd. of Elections, 383 U.S. 663 (1966) (striking down Virginia poll tax); Reynolds v. Sims, 377 U.S. 533 (1964) (correcting malapportionment with "one person, one vote" standard).

9. For example: Why are the poor and the black discrete and insular minorities worthy of special judicial solicitude, but not, say, burglars? Where do homosexuals, hippies, and anarchists fit in? Exactly how much are the poor entitled to? Which majority values are illegitimate prejudices and which are valid expressions of public morality? See Brest, The Substance of Process, 42 Oнго ST. L.J. 131 (1981); Tribe, The Puzzling Persistence of Process-Based Constitutional Theories, 89 YALE L.J. 1063 (1980).

10. Federal judges, for example, are not directly elected. Although the process of nomination and confirmation, the obligation to justify judicial decisions, and the possibility of impeachment are important mechanisms of judicial accountability, the judiciary is undeniably less electorally accountable than the two other branches of government.

11. When President Carter took office in 1977, "only 22 blacks or Hispanics and 6 women sat among the more than 500 active federal jurists." Slotnick, Lowering the Bench or Raising It Higher?: Affirmative Action and Judicial Selection During the Carter Administration, 1 YALE L. \& PoL'Y REv. 270, 271 (1983).

12. One might argue that the time for reflection that judges enjoy contributes to a less hurried and more informed decisionmaking than in the legislature. Any general comparative judicial advantage in factinding, however, at best extends only to narrow "adjudicative" facts to be gleaned from the record, not to the broader sorts of "legislative facts" that must inform the judge's attempt to apply a footnote-four jurisprudence. See 1 K. DAvis, Administrative LAW TREATISE $\$ 7.02$ (1958) (parties may often have little or nothing to contribute to development of legislative facts); D. HoROwrrz, THE CourTs AND Social PolicY 45-56 (1977) (pointing out barriers to accurate judicial determinations of legislative facts). Legislators can initiate investigations into subjects of interest; judges must wait for litigants to come to them and typically receive information only through formal submissions by advocates of self-interested parties who meet technical requirements for standing. Although increased judicial initiative and greater participation by amici might help to fill in the gaps created by the adversarial system, see Fiss, The Supreme Court, 1978 Term-Foreword: The Forms of Justice, 93 HARv. L. REv. 1, 25-26 (1979), a trial is no substitute for a legislative hearing. The rules of evidence constrain judicial factfinding, and ex parte communications-even with other judges not involved in the case-are unusual if not unethical. The legislator, in contrast, can regularly poll constituents and colleagues and can confer with anyone who might help flesh out the facts.

13. 347 U.S. 483 (1954) (separate is inherently unequal).

14. See, e.g., Civil Rights Act of 1964, Pub. L. No. 88-352, 78 Stat. 241 (codified as amended in scattered sections of 28 U.S.C. and 42 U.S.C. (1976 \& Supp. 1981)) (prohibiting discrimination in employment and in federally assisted programs); Fair Housing Act, Pub. L. No. 90-284, 82 Stat. 73 (1968) (codified as amended at 42 U.S.C. $§ \S 3601-31$ (1976 \& Supp. 1981)) (prohibiting discrimination in housing). 
borhoods, workplaces or schools-may erode or even destroy the distinctive culture of a minority group. Moreover, truly effective assimilation can be enormously intrusive, coercive, and expensive. Thirty years after Brown, an extraordinary number of whites still fight or flee forced racial integration. ${ }^{15}$

Thus, both Carolene Products and Brown are at best imperfect barriers to overweening majoritarianism. There is, however, a third approach that transcends the limitations of Brown and Carolene Products: We can restructure the legislature itself ${ }^{\mathbf{1 6}}$ so that minority interests are more fairly represented in the framing of legislation. This Note explores one possible restructuring-lottery voting. The Note uses this example of pure procedural justice ${ }^{17}$ as a theoretical model to illustrate the ways in which current voting rules deny minorities full legislative representation, and to offer an alternative vision of a more truly pluralistic selection of representatives. Before turning directly to the legislature, however, the Note considers briefly another pillar of Anglo-American democracy: the jury. This survey of the history and theory of the jury furnishes certain insights relevant to the process of selecting representatives. ${ }^{18}$

15. See generally Gewirtz, Remedies and Resistance, 92 YALE L.J. 585 (1983) (discussing obstruction and "white flight").

16. "[I]t must be remembered that legislatures are ultimate guardians of the liberties and welfare of the people in quite as great a degree as the courts." Missouri, K. \& T. Ry. v. May, 194 U.S. 267, 270 (1904) (Holmes, J.). See also Brest, The Conscientious Legislator's Guide to Constitutional Interpretation, 27 STAN. L. REv. 585 (1975).

17. The phrase is borrowed from J. RAwLs, A THeory of Justice $\S 14$, at 86 (1971): "[P]ure procedural justice obtains when . . there is a correct or fair procedure such that the outcome is likewise correct or fair, whatever it is, provided that the procedure has been properly followed." Lotteries are often presented as paradigmatic illustrations of pure procedural justice. See, e.g., B. ACKERMAN, supra note 2, at 289; Greely, The Equality of Allocation By Lol, 12 HARv. C.R.-C.L. L. REv. 113, 122 n. 43 (1977).

18. It should not be surprising that the American jury experience might have important implications for democratic theory in general and for the structuring of legislatures in particular. Indeed, one eminent jury theorist has written: "Each jury is a little parliament. The jury sense is the parliamentary sense." P. DEVL.IN, TRIAL BY JURY 164 (1956). For similar analogies between jurors and legislators as democratic representatives, see, e.g., R.H. LEE, Letters of a Federal Farner, Letter IV (October 12, 1787), in Pamphlets on the Constitution of the United States 316 (P. Ford ed. 1968) ("The trial by jury in the judicial department, and the collection of the people by their representatives in the legislature, are those fortunate inventions which have procured for them, in this country, their true proportion of influence, and the wisest and most fit means of protecting themselves in the community."); A. De TOCQUEvilie, Democracy in AmeriaA 291-97 (Vintage ed. 1945) ("The jury system as it is understood in America appears to me to be as direct and as extreme a consequence of the sovereignty of the people as universal suffrage. They are two instruments of equal power, which contribute to the supremacy of the majority. . . . The jury is that portion of the nation to which the execution of the laws is entrusted, as the legislature is that part of the nation which makes the laws. . .."). See also Federal Jury Selection: Hearings Before the Subcomm. on Improvements in Judicial Machinery of the Senate Comm. on the Judiciary, 90th Cong., 1st Sess. 256 (1967) (comments of Judge Irving R. Kaufman) [hereinafter cited as Jury Hearings]:

If the law is to reflect the moral sense of the community, the whole community -and not just a special part-must help to shape it. If the jury's verdict is to reflect the community's judgment-the whole community's judgment-jurors must be fairly selected from a cross-section of the whole community, not merely a segment of it." 


\section{LOTTERIES AND Democracy}

\section{A. The American Jury}

The jury has long been hailed as a cornerstone of democratic government, ${ }^{10}$ and as American democracy has evolved, so has the American jury. ${ }^{20}$ Until recently, jurors were often chosen by a "key man" system. Local selectmen were given discretion to handpick jurors of exemplary moderation and wisdom. In theory, these "blue ribbon" juries distilled the public morality. In practice, the "key man" system spawned a systematic underrepresentation on juries of the poor, the nonwhite, the young, the old, and women. ${ }^{21}$

In the past thirty years, however, a different conception of the jury has emerged. In this modern vision, which received its fullest judicial expression in Taylor $v$. Louisiana, ${ }^{22}$ the jury should represent "a fair cross section of the community." 23 To implement this vision, many commentators have called for, ${ }^{24}$ and many jurisdictions have adopted ${ }^{26}$ a "key number" system in which a lottery is used to generate the jury venire.

Though referring only to juries, Judge Kaufman's remarks would seem to apply a fortiori to legislatures, the true law-shapers. Of course, important institutional differences between juries and legislatures exist. See infra notes 45,131 . The jury is simply a convenient analogy.

19. In 1774, the First Continental Congress asserted that "the respective colonies are entitled to ... the great and inestimable privilege of being tried by their peers of the vicinage, according to the course of [common] law." Declaration of Rights of THE Continental Congress, art. 5 (1774). Two years later, the colonists' formal list of grievances against King George specifically included the deprivation "in many cases, of the benefits of Trial by Jury." ThE Declaration of INDEPENDENCE para. 19 (U.S. 1776). The ambiguity of the only provision in the original Constitution referring to juries, art. III, $\S 2, \mathrm{cl} .3$, was the source of considerable discussion and some apprehension during the ratification period. J. VAN DYke, JuRY Selection Procedures: OuR Uncertain Commitment to Representative Paneis 7 (1977). The passage of the Bill of Rights cured the ambiguity by elaborating on the right to a jury in no less than three of the first ten amendments. See U.S. ConST. amends. V, VI, VII. Yet another amendment that would have obliged state governments to furnish juries was adopted by the House, but deleted by the Senate. 1 ANNALS of CoNG. 78 (J. Gales ed. 1789).

For more recent expressions of the jury's importance as a palladium of American democracy, see Thiel v. Southern Pac. Co., 328 U.S. 217, 220 (1946) (celebrating "democratic ideals of trial by jury"); J. VAN DYKE, supra, at 1 ("The jury is the most democratic of our institutions."); Imlay, Federal Jun Refornation: Saving a Democratic Institution, 6 LOY. L.A.L. REv. 247 (1973).

20. See Glasser v. United States, 315 U.S. 60, 85 (1942) ("Our notions of what a proper jury is have developed in harmony with our basic concepts of a democratic society and a representative government.").

21. See J. VAN Dyke, supra note 19, at 23-44; Daughtrey, Cross Sectionalism in Jury-Selection Procedures After Taylor v. Louisiana, 43 TENN. L. REv. 1, 88 (1975).

22. 419 U.S. 522 (1975) (striking down under Sixth and Fourteenth Amendments Louisiana's exclusion of women jurors).

23. Id. at 527.

24. See, e.g., Report of the Committee on the Operation of the Jury System of the Judicial Conference of the Uniled Stales, 42 F.R.D. 353 (1967); J. VAN DYKe, supra note 19, at 16-19.

25. In 1968, Congress enshrined "the right to grand and petit juries selected at random from a fair cross section of the commurity" for federal court cases in the Jury Selection and Service Act, 28 U.S.C. § 1861 (1976) (emphasis added). See also UNIFORM JURY SELECTION AND SERvice ACT § 1, 13 U.L.A. 512 (1970) (providing for jury selection "at random from a fair cross section of the popula- 
The older vision, however, has not vanished altogether. Peremptory challenges at voir dire, in both civil and criminal cases, are still permitted in every state and in federal courts. ${ }^{28}$ Peremptory challenges stretch back to the colonial period, and have long enjoyed the blessing of the Supreme Court. ${ }^{27}$ Indeed, in the pre-Taylor case of Swain $v$. Alabama, ${ }^{28}$ the Court held that a prosecutor may use race-conscious peremptory challenges to reduce or eliminate minority group representation on a given jury. The tension between Swain and Taylor ${ }^{28}$ has energized a debate among contemporary commentators. Those who cling to Swain's conception of the jury have argued for extensive peremptory challenges to filter out jurors who might render the jury less moderate. ${ }^{30}$ In contrast, those who embrace Taylor favor severe restrictions on-if not outright abolition of-peremptory challenges, since such challenges enable lawyers to wrench an unrepresentative jury from a cross-sectional venire. ${ }^{31}$

Several insights flow from these developments in the law and theory of the jury. First, a tension clearly exists in democratic theory ${ }^{32}$ between the conception of democratic representatives as citizens of moderation and stature-men of the middle who each represent the soundest instincts and values of the community ${ }^{33}$ - and the conception of representatives as a cross-sectional group that collectively will be representative of all important subgroups ${ }^{34}$ within the community. ${ }^{35}$ Second, the lottery can plainly

tion of the area served by the court.") As of 1977, 33 states and the District of Columbia used key number systems based on random selection to generate "master wheels" for trial jury venires. J. VAN DYKE, supra note 19, app. A.

26. J. VAN DYKE, supra note 19, app. D.

27. See Hayes v. Missouri, 120 U.S. 68 (1887) (upholding peremptory challenge system). On the history of peremptory challenges, see J. VAN DYKE, supra note 19, at 145-51; Note, Limiting the Peremptory Challenge: Representation of Groups on Petit Juries, 86 YALE L.J. 1715, 1716-24 (1977).

28. 380 U.S. 202 (1965).

29. The Court recently denied certiorari in three cases involving the use of peremptory challenges to remove all blacks from juries. McCray v. New York, 103 S. Ct. 2438 (1983). Justices Marshall and Brennan, noting the apparent conflict between Swain and Taylor, dissented from the denial while Justices Stevens, Blackmun and Powell acknowledged the importance of the issue but preferred to allow further consideration of the question by state courts. Id.

30. See, e.g., Babcock, Voir Dire: Preserving "Its Wonderful Power," 27 Stan. L. Rev. 545 (1975) (arguing for defendant's right to peremptory challenge); Note, Peremptory Challenges and the Meaning of Jury Representation, 89 YALE L.J. 1177 (1980) (arguing for narrow reading of Taylor's cross-sectional requirement and for retaining prosecutorial challenges).

31. See J. VAN DyKE, supra note 19, at 166-69; Imlay, supra note 19, at 269-71; Note, supra note 27 , at $1733-41$.

32. It is unsurprising that this tension surfaces in debates about how the jury, our "most democratic" institution, should be structured.

33. This is, of course, precisely the philosophy underlying the peremptory challenge system. See Swain, 380 U.S. at 219 (peremptory challenges "eliminate extremes"); J. VAN DYKE, supra note 19, at 168 (peremptory challenges render "jury more homogeneous than the population at large").

34. This is the vision informing Taylor.

35. A similar tension exists in legislative theory: "[E]lected representatives can operate in two fundamentally different and contradictory ways: they can either reflect the sentiments and feelings of the people, or refine and improve upon their views. They can provide for likeness or competence." 
be a powerful tool to implement the cross-sectional ideal. ${ }^{36}$ Finally, the modern trend seems to be towards random selection and crosssectionalism. ${ }^{37}$

\section{B. Lotteries, Cross-Sectionalism, and Voting}

Except to choose jurors, Americans have rarely used the lottery as a serious part of their selection of representatives. ${ }^{38}$ Yet the use of the lot-

Rossum, Representation and Republican Government: Contemporary Court Variations on the Founders' Theme, 23 AM. J. JuRIs. 88, 104 (1978).

36. On the use of lotteries to affirm egalitarian values and recognize human dignity by promoting equality of opportunity and fair treatment, see Greely, supra note 17 . Greely demonstrates that lotteries can promote the ideals of both equal protection and due process, argues that random selection cnables "a democracy to reaffirm its commitment to human equality," id. at 141 , and concludes that lottery systems "should be considered more often," $i d$. Interestingly, it has been held in lifeboat situations, where some passengers must be starved or jettisoned to save the rest, that-where conditions permit-the selection must be made by lot. United States v. Holmes, 26 F. Cas. 360, 367 (C.C.E.D. $\mathrm{Pa}$. 1842) ("In no other than this or some like way are those having equal rights put upon an equal footing. . .."). Thus, majorities do not rule in the lifeboat polity. Cf. Jonah 1:7 (King James) ("So they cast lots, and the lot fell upon Jonah."). The lottery also figures prominently in recent literature in political philosophy on just and sensible social choice rules. See, e.g., Fishburn, Lotteries and Social Choice, 5 J. Econ. Theory 189 (1972) (discussing uses of lottery in response to problems created by Condorcet voting paradox ("Arrow's theorem")); Harsanyi, Can the Maximin Principle Serve as a Basis for Morality? A Critique of John Rawls's Theory, 69 AM. PoL. ScI. Rev. 594 (1975) (basing social choice rule on decisions individuals would make behind veil of ignorance if each had equal chance of inheriting any slot in distributive pattern of entitlements chosen behind veil).

37. The first two insights are paralleled by observations of Bruce Ackerman, who notes a tension in democratic theory between strict majority rule-i.e., rule by the median voter, the man in the middle-and allocation by lot: "[T]hinkers faced with the problem of pure procedural justice have often looked to the lottery as a mechanism that might fairly resolve some kinds of dispute. On the level of political practice, however, we have tended to resolve good-faith disagreements by an appeal to majority rule." B. ACKERMAN, supra note 2, at 289.

The third insight is strengthened by modern uses of lotteries in other areas to secure a more equal distribution of governmental benefits and burdens. The Vietnam War draft lottery, especially after the abolition of the college exemption, dramatically attests to the lottery's egalitarian power to distribute burdens cross-sectionally. See Greely, supra note 17, at 115 n.17. More recently, Congress has explicitly given the Federal Communications Commission discretion to use the lottery as part of its system for allocating broadcast licenses, 47 U.S.C. § 309(i) (West Supp. 1981); and the Department of the Interior has, where competitive bidding is not required, employed lotteries to determine which of several applicants will be permitted to lease government lands with oil and gas producing potential. 43 C.F.R. $\S 3112.4-1$ (a) (1982). For a thorough and prophetic discussion of the actual and potential uses of lotteries as allocative engines in a democratic society, see Greely, supra note 17; see also G. CALABRESI \& P. BOBBITT, TRAGIC ChOICES 41-44, 49 (1978) (discussing lotteries as allocative instruments).

38. The lottery and voting have occasionally intersected in American democracy. Under the "Hare" system of proportional representation, votes are initially tallied according to the voters' first choices, and then transferred in accordance with the voters' individual preference schedules from those candidates who cannot win or do not need the votes to win to those candidates who can and do. See J.S. Mill, Considerations on Representative Government 108-26 (C. Shields ed. 1958) (describing and praising "Hare" system); Note, Alternative Voting Systems as Remedies for Unlawful At-Large Systems, 92 YALE L.J. 144, 150-52 (1982) (discussing "Hare" system). Several cities have elected local legislative bodies by using random selection of "surplus" ballots in elections based on the "Hare" system. See Cambell v. Board of Educ., 310 F. Supp. 94 (E.D.N.Y. 1970) (rejecting challenge to use of geographic lottery as part of "Hare" system election of New York City's schoolboard); Moore v. Election Comm'rs, 309 Mass. 303, 305 N.E.2d 222 (1941) (upholding "Hare" system with lottery selection of "surplus" votes in Cambridge, Mass.); Silva, Relation of Representation and the 
tery to select leaders has venerable historic roots. In ancient Athens, sortition was a prominent feature of the representative-selection process under the Cleisthenic Constitution; ${ }^{38}$ the Venetian republic also relied heavily on the lot. ${ }^{40}$ America's rejection of these ancient models for selecting assemblies is readily understandable. An assembly selected by lot is a collectively representative sample of the underlying pool ${ }^{\mathbf{4 1}}$ (presumably, the polity as a whole), ${ }^{42}$ but in an important sense, its individual members are not complete representatives because they are not accountable to constituent groups in the polity in the way that modern legislators are. ${ }^{43}$ If candidates are elected by citizen votes, those who do not correctly represent the interests of their constituents will lose. If, however, seats in the assembly are distributed purely by lot, the reward of legislative tenure is wholly disengaged from past or promised job performance. No matter how popular a "candidate" is, he stands the same chance of "election." how well an incumbent does his job, he stands the same chance of "reelection." 45

The cross-sectional ideal behind the lottery, however, remains a powerful and informing vision in electoral theory. The promise of Reynolds $v$. Sims' "one person, one vote" principle, for example, is that all votes will count equally. ${ }^{46}$ Yet the reality of Reynolds is that when representatives are selected by majority rule, the votes of those in the minority do not truly count. ${ }^{47}$ Because of gerrymanders, ${ }^{48}$ geographic dispersion of minority

Party System to the Number of Seats Apportioned to a Legislative District, 17 W. PoL. Scr. Q. 742, 758 (1964) (citing examples of Kalamazoo, Ashtabula, Cleveland, and Sacramento). For a more detailed treatment of Cambell and Moore, see infra note 126.

The lot is also sometimes used to determine placement of candidate names on the ballot. See McCoy v. Mayer, 333 F.2d 151, 152 (D.C. Cir. 1964). Lotteries are regularly used to break tie votes. See IL.. Const. art. IV, § 3(b). Additionally, the Jury Selection and Service Act of 1968, 28 U.S.C. § 1863 (1976), and many state statutes use voter registration rolls as a first approximation of the pool from which jury venires are to be randomly selected. See J. VAN DYKE, supra note 19, app. A.

39. See A. Jones, Athenian Democracy 100-07 (1969).

40. See R. Finlay, Politics in Renaissance Venice 141-42 (1980).

41. Of course, the larger the assembly, the more likely it is to be an accurate cross-section of the community. See T. WonNacotT \& R. WONNACOTT, INTRODUCTORY Statistics fOR Business AND ECONOMICs 73-107 (1977). Cf. infra note 60 (presenting statistical likelihood of success under lottery voting for hypothetical minority party).

42. See infra note 70 (discussing pool definition).

43. See H. Pitkin, The Concept of Representation 73-75 (1967).

44. This defect of a pure lottery is not shared by lottery voting. See infra p. 1299.

This Note uses the words "he" and "his" generically to apply to both genders. The choice of the masculine pronouns was determined by lot.

45. This feature seems less problematic in jury selection: Unaccountability has historically been a hallmark of the American jury. Never asked to give reasons for its verdict, the jury is the paradigmatic "black box." See G. CAlabresi \& P. BobBITT, supra note 37, at 57-62. For a further discussion of relevant differences between juries and legislatures, see infra note 131 .

46. Reynolds v. Sims, 377 U.S. 533 (1964) (individual votes must count equally).

47. In effect, these minority votes are "counted"-i.e., tallied-and then ignored. As Ralph Rossum states:

In the winner-take-all system of electing legislators employed in the United States, there is 
groups, ${ }^{49}$ and the single-ballot voting rules in effect in most jurisdictions, ${ }^{30}$ discrete and insular groups are systematically underrepresented in current legislatures. ${ }^{\text {s1 }}$ In a real way, the current system has wasted their votes instead of counting them equally, and the "one person, one vote" promise of Reynolds has been breached.

simply no such thing as "equal representation." By its very nature, it discriminates by rejecting the will of the minority voters. Legislators tend to represent the interests of the majority coalition that elects them, not the total population of their district. "Equal representation for equal numbers of people" can be achieved only through the adoption of some system of proportionate representation.

Rossum, supra note 35, at 91 . For an acknowledgment of the implications of the current winner-takeall approach to legislative elections, see Whitcomb v. Chavis, 403 U.S. 124, 153 (1971) (under current system, dominant party in district can win "year after year"). See also Sickels, Dragons, Bacon Strips and Dumbbells-Who's Afraid of Reapportionment?, 75 YALE L.J. 1300, 1304 (1966) (discussing "wasted votes").

In one sense, it could be argued that all votes are fully counted because every vote is essential in determining which single vote is the median that decides the outcome. This argument, however, masks the real power of the general legislature to decide by its district map that a certain group of voters will be the all-important median bloc in a given district. The power to draw district lines is the power to decide which groups shall wield real power in a district and which groups shall be relegated to perpetual minority status. See infra pp. 1293-96. Moreover, the argument rests on a simplistic conception of society as one collective and homogeneous body politic whose center of gravity is to be located, instead of as an agglomeration of parties and subgroups with distinct interests requiring distinct representation. See infra pp. 1296-97.

48. Courts can prevent only the most blatant gerrymanders. Compare Gomillion v. Lightfoot, 364 U.S. 339,341 (1960) (striking down "strangely irregular twenty-eight-sided" district designed to exclude black voters) with Gaffney v. Cummings, 412 U.S. 735, 752 n.18 (1973) ("[C]ompactness or attractiveness has never been held to constitute an independent federal constitutional requirement for .. . legislative districts.") and Wright v. Rockefeller, 376 U.S. 52 (1964) (upholding boundary line between congressional districts where one district was $94.9 \%$ white and other was $86.3 \%$ black and Puerto Rican, and where there were some irregularities in boundaries and variations in total population).

49. This dispersion makes it impossible to create a "safe" district in which a minority group commands a local majority. See Kirksey v. Board of Supervisors, 402 F. Supp. 658 (S.D. Miss. 1975), aff'd, 528 F.2d 536 (5th Cir. 1976), rev'd 554 F.2d 139 (5th Cir.) (en banc), cert. denied, 434 U.S. 968 (1977) (racially "neutral" plan reapportioning single-member districts gave blacks, who comprised $39 \%$ of the overall population, minority of voting-age population in all five districts).

50. See Silva, supra note 38 , at 743-44 (single-ballot plurality vote would rarely produce legislature accurately reflecting various parties' statewide strength, even if districts drawn impartially); see also infra p. 1292 (describing currently dominant voting rules).

51. Blacks, for example, account for about $11.9 \%$ of the population, Portrait of America, NEwsWEEK, Jan. 17, 1983, at 33, but only about 1\% of all elected officials, Seeking Votes and Clout, TIME, Aug. 22, 1983, at 21. There has never been an elected black governor in this nation's history, nor, of course, a black President. Although this Note does not intend to suggest that only a black can truly represent fellow blacks, the stunning discrepancy between the percentage of black citizens and black leaders should give us great pause. This Note contends that the systematic underrepresentation of blacks is no mere happenstance, but a thoroughly predictable consequence of the prevalent modes of electing public officials. A $10 \%$ minority may well be outvoted $100 \%$ of the time; it may never get to elect its preferred candidate, and its interests may never be fairly-that is, proportionately-represented in lawmaking bodies. Cf. J. ELY\} supra note 4, at 82: "Naturally, that cannot mean that groups that constitute minorities of the population can never be treated less favorably than the rest, but it does preclude a refusal to represent them . . . ." (emphasis in original). 


\section{LOTTERY VOTING}

Cumulative voting ${ }^{\mathbf{6 2}}$ has been suggested as a way to preserve the accountability guaranteed by the ballot box while fulfilling the promise of Reynolds through the election of a cross-sectional legislature. ${ }^{53}$ In an ideal cumulative voting system, the legislature is collectively representative of the polity, while each member is accountable to his constituent group and is responsible for representing that group's interests. There is, however, another voting method that also preserves accountability while promoting cross-sectionalism: lottery voting. Featuring both lottery and ballot box, this system seeks to combine the best elements of the Athenian and American models of representation. Though it has never been used before, lottery voting has powerful appeal as a theoretical model, and enjoys several practical advantages over majority, plurality, and cumulative voting.

\section{A. Lottery Voting Compared to the Current System}

At present, the dominant methods for choosing legislators are based on the single-ballot rule, ${ }^{54}$ with the winner determined by either a plurality or majority of votes cast. ${ }^{55}$ For congressional elections, single-member districting is required, ${ }^{56}$ whereas state legislatures use both single-member and multi-member districts. ${ }^{57}$ The kinds of legislatures spawned by most current voting systems are sufficiently similar to be considered together ${ }^{88}$ and contrasted with the kind of legislature likely to emerge under lottery voting. ${ }^{58}$

52. Cumulative voting requires multi-member districts; each voter is permitted to cast a number of votes equal to the number of seats apportioned to his district, and to divide those votes among candidates as he sees fit. He can "bullet" by casting all his votes for a single candidate, or can divide his votes among several candidates. "Bulleting" enables a rather small minority to guarantee itself representation in any district that has a large number of seats: In a district with $n$ seats, a party having the support of only $1 /(n+1)$ th of the voters could assure itself of a seat by running one candidate for whom all party supporters "bullet" their vates.

53. See Note, supra note 38 , at 153-60 (praising cumulative voting).

54. Unlike voting schemes such as the "Hare" system, see supra note 38 , a single-ballot rule does not allow voters to rank candidates in order of preference.

55. In 1964, 98 out of 99 state legislative chambers were elected under a single-ballot plurality rule. See Silva, supra note 38 , at 742 . Since then, some states have switched to a single-ballot majority rule. See GA. Code ANN. § 21-2-501 (1982). For elections to the U.S. Congress, some states have adopted a single-ballot plurality rule while others use a single-ballot majority rule. In the absence of a uniform rule propounded by Congress pursuant to Article I, $\S 4$, states may adopt either rule. Phillips v. Rockefeller, 435 F.2d 976 (2d Cir. 1971); Bond v. Fortson, 334 F. Supp. 1192 (N.D. Ga.) (dictum), aff'd mem., 404 U.S. 930 (1971).

56. 2 U.S.C. \& 2 (c) (1982).

57. In $1970,46 \%$ of the upper houses and $62 \%$ of the lower houses contained some multi-member districts. Whitcomb v. Chavis, 403 U.S. 124, $156 \mathrm{n.37}$ (1971). For a history of the various voting rules that have been applied at the state and federal level, see id. at 156-60.

58. Cumulative voting, however, is sufficiently different to warrant special treatment. See infra pp. 1300-03.

59. This is not to deny that important differences exist among prevalent voting systems. For example, multi-member districting combined with a prohibition against "bulleting," see supra note 52, 


\section{Proportional Representation and Cross-Sectionalism}

The law of averages ensures that, at any given time, an assembly selected by lottery voting would substantially reflect the underlying distribution of votes in the polity. For example, in a legislature with one hundred seats, a slate of minority candidates with the support of five percent of the citizens would-with at least ninety percent certainty-win between two and eight seats. ${ }^{60}$ Unlike the current system, lottery voting would thus automatically effect a proportionately representative legislature. The result would be a fluid and natural "quota" system of representation with each group of voters ${ }^{61}$ receiving its proportionate slice of total legislative representation. ${ }^{62}$ This general characteristic would affect the structure of politics in several ways.

The real tragedy of Reynolds $v$. Sims and its progeny has been the

results in "at-large" voting that dramatically exacerbates the already-strong majoritarian bias of single-district voting. See Whitcomb v. Chavis, 403 U.S. at $134 \mathrm{n} .11$ (party receiving over $48 \%$ of popular vote loses every seat to majority party after at-large voting). See also Note, supra note 38 (describing and criticizing at-large voting).

60. If the party controls $5 \%$ of the vote within each district, the probability that it will receive less than two seats is less than $4 \%$, and the probability that it will capture more than 8 seats is about $6 \%$. See T. WonnacotT \& R. Wonnacotr, supra note 41 , at $84,168-70$ (offering formulae for computing probability). Two additional points deserve mention. First, even though the party could be so unlucky as to lose every seat in a given legislature-the likelihood of this is less than $0.6 \%$-the odds that it would be unrepresented in two consecutive legislatures are virtually infinitesimal: (.006) $\times(.006)=0.000036$. Second, if party members are less geographically dispersed, the odds that the party would win between 2 and 8 seats are much higher. If, for example, the party accounts for all the voters in 5 of the equally populous districts and has no supporters in any other district, it would aluays win those 5 seats, exactly $5 \%$ of the total.

61. The relevant group membership of a voter is defined not by his inherited or socio-economic endowments, see supra note 3 , or by his geographic residence, see infra note 62 , but by his very vote itself. By casting his ballot for the candidate of a given party, the voter chooses to identify his interests with those of other party voters. This is the group most relevant to each voter's political identity, and thus this is the group that deserves proportional representation.

62. Cf. Gaffney v. Cummings, 412 U.S. 735, 736, 754 (1973) (upholding against equal protection challenge policy of "political fairness" which aimed at a rough scheme of proportional representation of two major political parties). Lottery voting and cumulative voting simply extend the principle of "political fairness" to all parties. See infra pp. 1296-97.

Currently, the only quota system is geographical, with each equal-sized district being guaranteed, by the very fact of district elections, its fair share-its quota - of total representation in the legislature. For a classic illustration of a quota system designed to protect geographic minorities, see U.S. ConST. art. I, $\S 2$, cl. 3 ("direct Taxes shall be apportioned among the several States . . . according to their respective Numbers"); The Federalist No. 36, at 220 (A. Hamilton) (C. Rossiter ed. 1961) (proportional taxation "effectually shuts the door to partiality or oppression"). Earlier in The Federalist, quota representation of all groups is described as impracticable: "The idea of an actual representation of all classes of the people by persons of each class is altogether visionary . . . [T] his will never happen under any arrangement that leaves the votes of the people free." THE FEDERALIST No. 35, at 214-15 (A. Hamilton). Both cumulative voting and lottery voting seek to bring a measure of reality to that "visionary" ideal, although neither system requires the people of "each class" to vote for persons of that class as representatives. Class members are always free to vote for candidates who, although not members of the class, may be seen as better representatives of the class interests. See supra note 51; $f$. Fiss, supra note 12, at 18-22 (best class representative in structural reform lawsuit need not be member of victim class). 
inability of courts effectively to prevent subtle gerrymanders, ${ }^{63}$ whether racial, ideological, religious, or economic: ${ }^{84}$ There is no truly neutral benchmark against which to measure a state's districting plan, ${ }^{65}$ and even the most obvious racial gerrymanders can entangle judges in thorny political thickets. ${ }^{6 B}$ Ironically, Reynolds' command itself furnishes an excellent pretext to gerrymander, since periodic redistricting is constitutionally required. ${ }^{67}$

The problem is that new district lines are not drawn behind a Rawlsian "veil of ignorance." ${ }^{18}$ A majority party knows that drawing the lines one way yields $\mathrm{X}$ safe districts, but another way, only $\mathrm{X}$ minus $\mathrm{A}$. Under lottery voting, however, no matter how the lines were drawn, a party could not alter the expected number of districts that it would win so long as districts contain equal numbers of voters. ${ }^{69}$ Because each citizen within a district would have an equal chance that his vote would determine the outcome of the election, ${ }^{70}$ votes of local minorities could not be effectively

63. "The question of the gerrymander is the other half of Reynolds . . . ." Whitcomb v. Chavis, 403 U.S. 124, 176 (1971) (Douglas, J., dissenting in part).

64. See Cousins v. City Council, 466 F.2d 830, 847, 857-61 (7th Cir.) (Stevens, J., dissenting) (political groups have same constitutional right as racial groups to be free from invidious gerrymanders by which "the 'ins' maximize[ ] their ability to exclude the 'outs" "), cert. denied, 409 U.S. 893 (1972). For a further elaboration of Justice Stevens' views about nonracial gerrymandering, see Karcher v. Daggett, 103 S. Ct. 2661, 2667-78 (1983) (Stevens, J., concurring); City of Mobile v. Bolden, 446 U.S. 55, 86-89 (1980) (Stevens, J., concurring in the judgment).

65. Thus, although the first half of Reynolds, the equal size requirement, is judicially manageable, see infra p. 1296, the second half-the drawing of district lines, see supra note 63-is far less so, as Justice Harlan argued so presciently in his Reynolds dissent: "No set of standards can guide a court which has to decide how many legislative districts a State shall have, or what the shape of the districts shall be, or where to draw a particular district line." 377 U.S. 533, 621 (1964).

66. See United Jewish Org. v. Carey, 430 U.S. 144 (1977) (upholding districting plan designed to maintain black representation that dissipated Jewish voting strength by carving up Hasidic Jewish neighborhood).

67. Reynolds, 377 U.S. at 583.

68. A veil of ignorance denies individuals access to morally arbitrary and irrelevant information. See J. Rawls, supra note 17 , at $\$ 24$, at $136-42$.

69. It could, however, reduce the variance around that mean, but this does not seem especially problematic. The more each district is microcosmic of the overall jurisdiction, the wider the spread around the mean number of seats a given party can expect to win. For an illustration, see supra note 60 .

70. Lottery voting thus offers true "equality of opportunity." See Greely, supra note 17, at 122 ("Random selection is the only allocative method which honestly can claim the objective equality of opportunity .... ."). Moreover, one of the most problematic stages of most lotteries-defining the overall pool (the equality of whose members the lottery affirms)-is extraordinarily straightforward in lottery voting: All those who vote are automatically members of the pool. Cf. id. at 118-20 (definition of pool allows discretion that may frustrate lottery's goal of affirming equality, but at least choices made in defining pool are highly visible).

Lottery voting's equality of opportunity resonates with recent language inserted into the Voting Rights Act protecting the right of racial minorities to equal "opportunity . . . to participate in the political process and to elect representatives of their choice." 42 U.S.C.A. $\$ 1973$ (b) (West Supp. 1983) (emphasis added). The Act, however, establishes no right "to have members of a protected class elected in numbers equal to their proportion in the population." Id. Neither does lottery voting. See supra notes 51,62 .

For an argument that the true meaning of Reynolds v. Sims is that each voter should have an equal 
erased or diluted by clever districting. ${ }^{71}$ By forcing majorities ${ }^{72}$ to draw district maps behind a "veil of ignorance," lottery voting would thus prevent gerrymanders, ${ }^{73}$ protect minorities, and transform redistricting into a system of "perfect procedural justice."

Lottery voting would also protect the geographically dispersed minority. Currently, if, for example, a forty percent black minority is not clustered together (in which case an attempt to split up its voting strength might be too obvious to escape judicial remedy) the sixty percent white majority could in all good faith district the state so that no district had a black majority or near-majority. ${ }^{70}$ The perverseness of the current system is extraordinary: Blacks can guarantee themselves a fair share of representation only by segregating themselves. ${ }^{76}$ With lottery voting, in contrast,

chance to cast a decisive vote, see Banzhaf, Multi-Member Electoral Districts-Do They Violate the "One Man, One Vote" Principle, 75 YALE L.J. 1309 (1966). Banzhaf's analysis harmonizes with recent work in game theory, see id. at 1317 , and demonstrates that equal-size districting creates a sort of a priori equality of decisional power among voters. In actuality, however, the true weight of a citizen's vote under current voting rules depends on the votes of those around him and thus can never be truly equalized across all voters. See Whitcomb v. Chavis, 403 U.S. 124, 168-69 (1971) (separate opinion of Harlan, J.); A. Downs, An Economic Theory of Democracy 244 (1957). Under lottery voting, by contrast, the likely or actual voting behavior of others in no way affects the likelihood that a given citizen's vote would decide the election. Equality of voters within districts is guaranteed by the lottery, while equality of voters across districts within the jurisdiction follows automatically from equal-size districting. See infra pp. 1295-96.

71. See Howard v. Adams County Bd. of Supervisors, 453 F.2d 455 (5th Cir. 1972) (upholding district map giving blacks a clear majority in only 1 out of 5 districts, where blacks accounted for $48 \%$ of total population).

72. In fact, under the current system, a dominant plurality group can, in theory, control the legislature even if individual district elections require a majority vote. A party with $26 \%$ of the citizens could, if its members were correctly distributed geographically, win a bare majority of seats in the legislature, winning each seat by a bare majority. The problem of a legislature selected by majority vote that in turn relies on majority rule is akin to the danger of rounding off an already-rounded number. $C f$. J. Bonbright \& G. Means, The Holding Company 18-20, 108-13 (1932) (discussing Samuel Insull's infamous holding company pyramid of the 1920's). Thus, the "one person, one vote" rule of Reynolds, without more, can guarantee neither proportional representation nor ultimate majoritarianism. Lottery voting, on the other hand, effects proportional representation within the legislature without ultimately sacrificing majoritarianism, since the legislature selected by lottery voting would itself use majority rule. See infra pp. 1303-04.

73. Interestingly, in The Federalist, Hamilton argues that a natural geographic lottery would prevent a "gerrymandering" of the place of local elections:

Are the wealthy and the well-born, as they are called, confined to particular spots in the several States? . . . Or are they, on the contrary, scattered over the face of the country as avarice or chance may have happened to cast their own lot or that of their predecessors? If the latter is the case (as every intelligent man knows it to be) is it not evident that the policy of confining the places of elections to particular districts would be subversive of its own aim ...? The Federalist No. 60, at 370-71 (C. Rossiter ed. 1961) (emphases added; footnote omitted).

74. The phrase is John Rawls" and applies whenever "there is an independent criterion for what is a fair division" (here, equality of voting strength across all voters) and "a procedure that is sure to give the desired outcome" (here, lottery voting). Rawls, supra note 17 , at 85 . Indeed, the example Rawls offers of a system of perfect procedural justice can be seen as an evocative metaphor for districting under lottery voting: A cake must be divided into a number of "equal" portions, so one person cuts, while others choose. See R. Luce \& H. Raiffa, Games and Decisions 363-68 (1957).

75. See supra note 49.

76. And of course, even if blacks are geographically segregated, their neighborhoods may not be populous enough to comprise a majority in any district. 
four out of every ten legislators (on average) would be chosen by (randomly selected) ballots cast by black citizens, no matter how dispersed blacks were, so long as each district were of equal size. This last requirement is a neutral one that courts can easily police. ${ }^{77}$ Lottery voting would thus prevent the district map from converting Reynolds' noble ideal of "one person, one vote" into a farce.

\section{Party Structure}

Like cumulative voting, lottery voting would tend to erode the twoparty system by allowing minor parties to spring up and flourish. The two-party system exists today only because of the voting rules now in force. Individuals are often forced to vote for the lesser of two major-party evils because a third-party candidate, although perhaps attractive to many, cannot hope to muster the requisite majority to win. ${ }^{8}$ Under lottery voting, by contrast, every voter could rationally cast his vote for the candidate who is truly his first choice. ${ }^{79}$ Moreover, the current system creates enormous electoral economies of scale and financial barriers to entry. Currently, unless a party can put together a majority or dominant plurality coalition-no inexpensive feat-its efforts are worthless insofar as its goal is simply to elect a representative. ${ }^{80}$ Lottery voting is not similarly skewed

77. Sep J. Ely, supra note 4, at 124-25.

78. A. Downs, supra note 70, at 124; M. Duverger, Political Parties 217 (1967); D. Rae, The Political Consequences of Electoral Laws 95-96 (1967); V. Key, Politics, Parties, AND PREssure Groups 224-31 (1952). These works establish that, under current voting rules, longterm equilibrium rarely permits more than two parties in a given district. The fact that every district has the same two parties is a result of certain electoral economies of scale and the "ticket" system created by statewide and national elections.

79. Currently, a rational voter cannot always vote for his favorite candidate, because doing so may increase the likelihood that a less favorite candidate will win. See A. Downs, supra note 70 , at 47. This perversity cannot occur under lottery voting. The current system thus gives rise to Condorcet and other voting paradoxes that create incentives for strategically insincere voting. Lottery voting cures the potential irrationalities and perversities of current collective choice rules, see generally A. SEN, CoLLective Choice and Social Welfare (1970), by introducing a suprarational and neutral instrument (the lot) that disaggregates collective behavior and emphasizes individual moral responsibility, see infra pp. 1299-1300. As a result, rational voting can become a true "preference revealing" act. See A. Feldman, Welfare Economics and Social Choice Theory 112-25 (1980) (discussing preference-revealing incentive schemes).

80. Although a party may have ancillary goals, the election of representatives is the raison d'etre of the electoral system. Moreover, many subsidiary aims of a minority party would probably be better served by lottery voting. If the party seeks to educate the electorate about its views, it is far more likely to attract publicity if its candidate has some possibility of winning. Similarly, if the goal is to influence the platform of a major party, lottery voting allows a minority party to threaten to withhold its support from an undesirable major-party platform without increasing the likelihood that an even less attractive party will win. See supra note 79. Minority parties are thus in a better position to secure compromises from the major parties. Finally, even if a minority group could succeed in securing concessions on a major party platform, group members would likely be far better off if they could instead elect their own first-choice candidate, who could be a better representative in legislative hearings, negotiations, and debates than a major party candidate who-however faithful to the platform-has no personal commitment to the minority plank forced upon him. See generally Note, Affirmative Action and Electoral Reform, 90 YALE L.J. 1811, 1812-14 (1981) (describing other benefits 
towards the well-heeled, since it does not ignore votes for small parties with low budgets.

Lottery voting contemplates a legislature in which individual members are leaders of, spokesmen for, and accountable to, the many diverse groups (parties) that make up the polity. ${ }^{\mathbf{8 1}}$ This more diverse legislature would vindicate the ideal of Madison's Federalist No. 51, which argues that "justice and the general good" will flow from the "great variety of interests, parties, and sects" embraced by the legislature. ${ }^{82}$

\section{Rotation of Officeholding Within Districts}

In any given district, lottery voting would result in more rotation of officeholding. Even an incumbent with the consistent support of most of his constituents could not guarantee himself perpetual re-election. The upshot of lottery voting would be a turn-taking system of representation within districts. ${ }^{83}$ Over time, every group in a community would get its

of increased minority representation).

81. It is sometimes argued that a multi-party system inevitably breeds instability and confusion. A. Downs, supra note 70 , at 142-63. Such an argument, however, is based on a parliamentary model, and cannot be blindly extrapolated to American legislatures. In a parliamentary system, a bloc of parties with a legislative majority forms the "government" coalition while other parties form the "opposition." The executive officers who run the government must at all times command the backing of a legislative majority, since the defection of a swing party on any important issue can topple "the government" and trigger new elections. Such obstacles to shifting legislative alliances and full pluralism do not exist in the American system, where legislature and executive are separate.

82. THE Federalist No. 51, at 325 (C. Rossiter ed. 1961). Although this passage speaks to diversity within the polity, The Federalist goes on to note that such diversity would:

occasion a material diversity of disposition in [the] representatives .... In proportion as either [interest] prevails, it will be conveyed into the national representation; and for the very reason that this will be an emanation from a greater variety of interests and in much more various proportions than are to be found in any single State, it will be much less apt to espouse either of them with a decided partiality ....

ThE Federalist No. 60, at 367-69 (A. Hamilton) (emphases added); see The Federalist No. 59, at 360 (A. Hamilton) (legislature should be composed to secure "a sufficient number for the purposes of safety, of local information, and of diffusive sympathy with the whole society") (emphasis added); sep also J. ELY, supra note 4, at 122 ("Many among the framers stressed the importance to the system they were forging of the equal representation of equal population groups."); 1 M. FARRAND, THE RECORDS OF THE FEDERAL CONVENTION OF 1787, at 132 (1937) (remarks of James Wilson at the Constitutional Convention) ("The legislature ought to be the most exact transcript of the whole society.").

The early Federalists, however, also favored larger districts and at-large elections in order to promote election of "the worthy." See G. WoOd, The GREation of tHe AMERICAN Republic, 1776-1787, at 471-518 (1969). Thus, Federalist writings often exhibit a serious tension: They wanted a legislature that would reflect, and yet at the same time refine, community sentiment. To the extent that modern legislators do not today have the sort of independence from their constituents that Madison envisioned, today's assemblymen no longer refine the passions of the majority coalitions that elected them as Madison hoped they would. Thus, it is all the more important to harken to the other half of the Madisonian prescription calling for legislative diversity and pluralism. Nor need truer reflection mean less refinement. One of the virtues of lottery voting is that legislators will continue to be individuals of stature-acknowledged leaders of the various groups that comprise the polity. See infra note 131.

83. The ancient Athenian system also featured turn-taking, with each of ten tribes running the city government for 35 days a year. A. JoNEs, supra note 39, at 106. In the 1770's rotation of 
fair stint of representation. Lottery voting would thus gradually integrate growing outgroups ${ }^{84}$ into government and would avoid the problems of political "tipping" that now occur when a former minority reaches fiftyone percent of the total district population. ${ }^{85}$ Moreover, because a solid majority in a given locality could not guarantee itself a perpetual monopoly on the district seat in the state legislature ${ }^{86}$ it would have an incentive to treat the minority more kindly. The uncertainty of outcome that a lottery introduces is a check against injustice and self-interest, promoting more even-handed laws. ${ }^{87}$

Lottery voting would create a legislature of rotating citizen-legislators instead of an entrenched group of lifetime lawmakers. ${ }^{88}$ While legislators elected by lottery voting might have (on average) less "expertise," they would be in closer touch with the needs and concerns of fellow citizens in the real world of the polity. ${ }^{89}$ Furthermore, the fact that incumbents could

officeholding was a "cardinal tenet" of American republicanism, G. WooD, supra note 82, at 140-41; for example, the Pennsylvania government formed in the summer of 1776 was "permeated" with the principle of mandatory rotation, $i d$. at 87 . The disregard of this principle in the federal constitution sparked widespread protest. Id. at 521-22. Indeed, the absence of mandatory rotation and of a bill of rights were Thomas Jefferson's two major criticisms of the Constitution. See Letter from Thomas Jefferson to James Madison (July 31, 1788), reprinted in 5 Writings of Thomas Jefrerson 43-48 (P. Ford ed. 1895).

84. Many racial minority groups are growing as a percentage of the total population. See Portrait of America, NewsweEk, Jan. 17, 1983, at 22.

85. Currently, when a long-excluded outgroup finally comes into power, it may come in with a vengeance-with little experience running government and little taste for compromise.

86. Under lottery voting, access to the "natural monopoly" of a legislative district seat would be controlled by a "common carrier" approach instead of by "regulation" by the median voter in that district. Although Ely claims that his theory of judicial review resembles an "antitrust" as opposed to a "regulatory" approach to structural imperfections in the political marketplace, see J. ELY, supra note 4 , at $102-03$, his prescriptions are far more regulatory than he would like to admit. See supra note 9. In essence, Ely would have courts impose a substantive "fairness doctrine" on the political marketplace. The approach argued for in this Note is, by contrast, more analogous to an "equal time" or "equal opportunity of access" provision, see supra note 70, and is thus more akin to the obligation imposed on a common carrier to furnish equal access to all potential patrons.

87. In a similar vein, James Wilson proposed at the Constitutional Convention that the President be elected by a group of electors to be chosen "by lot from the national legislature." $2 \mathrm{M}$. FARRAND, supra note 82, at 103. The uncertainty of the lot, it was argued, would thwart petty intrigue and factionalism. Id. Cf. The Federalist No. 78, at 470 (A. Hamilton) (C. Rossiter ed. 1961) ("[N]o man can be sure that he may not be tomorrow the victim of a spirit of injustice, by which he may be a gainer today."). For other discussions of the ways in which a "veil of ignorance" leads to justice, see J. RAwls, supra note 17 , at $\$ \S 23-24$, at 130-42; Plato, The RePuBlic, 460a- 464e (suggesting that mating lottery, by cloaking actual kinship ties, would encourage each citizen to treat all members of his generation as his siblings, all elders as his parents, and all youths as his children).

88. A central tenet of early American republicanism was the belief that "representatives should meet frequently and for a short time to correct the laws, returning immediately to private life to experience the consequence of their actions along with other members of the society." G. Woon, supra note 82 , at 25 . The principles of short service, rotation, and citizen participation remain important components of modern jury theory. See J. VAN DYKE, supra note 19, at 111-34, app. M.

89. The value of legislative "expertise" has probably been overestimated. The proper function of the legislature is not to draft narrow, technical codes, but to make basic policy choices by setting priorities among competing values and establishing the general contours of acceptable tradeoffs. See J.S. MrLl, supra note 38, at 68-84. Ironically, current legislatures often fail to address fundamental issues while enacting extremely complex statutory schemes. See Industrial Union Dep't, AFL-CIO v. 
not guarantee themselves re-election might well encourage them to adopt a longer decisional time-horizon than the next election. ${ }^{90}$

\section{Incentives For Voters And Candidates}

Although even a popular incumbent could not guarantee himself lifetime tenure in the legislature, lottery voting would not destroy political accountability. Unlike a pure lottery, lottery voting does not ignore the ballot box; the more popular a candidate, the greater his chances of victory. Indeed, lottery voting would emphasize the marginal voter in a way that the current system cannot. Under lottery voting, an incumbent would always have a strong incentive to please more constituents. Ex ante, there would be a tremendous difference under lottery voting between a $51 \%$ / 49\% margin over an opponent and a $90 \% / 10 \%$ lead. $^{91}$

Nor would lottery voting discourage people from voting. Although it is quite unlikely that any given individual's ballot will be the one picked out of the twirling basket-the one that "counts"-a rational individual does not expend time, energy, and money to vote because he seriously believes that his vote will determine the outcome of the election. Almost no election for a representative is ever decided by one vote, so virtually no individual's vote has ever "counted" in that strong sense. ${ }^{92}$ Individuals vote predominantly because of a sense of individual civic obligation, acquired by socialization, to participate in the community's decisionmaking process. ${ }^{93}$ If an-

American Petroleum Inst., 448 U.S. 607, 672 (1980) (Rehnquist, J., concurring) (Congress refused to strike basic tradeoff between safety and profits).

90. Instead of fixating on the upcoming election, party leaders would seek to maximize the longterm popularity of the party (and thus the proportion of time they can expect to spend in office). Any temptation to plunder the spoils of incumbency created by the uncertainty of re-election could be restrained through mechanisms of party discipline and ideology, as is currently the case for retiring Senators or second-term Presidents.

91. Of course, marginality exists currently to the extent that an incumbent often prefers a landslide re-election to a squeaker, especially if he aspires to a still-higher office. But the 51st vote out of 100 is still all-important, and a current incumbent has little or no incentive to reach out to a minority group if by doing so he might threaten his solid electoral base. Suppose, for example, that an incumbent with a $60 \%$ approval rating confronts a situation in which he stands a $90 \%$ chance of wooing an additional $30 \%$ of the electorate, and a $10 \%$ chance of failing to please the new constituents and alienating half of his old ones. Even though the expected value of the votes to be gained $(90 \% \times 30 \%=27 \%)$ dwarfs the expected value of votes lost $(10 \% \times 30 \%=3 \%)$, he would likely avoid the potentially base-broadening move. He will then assuredly win under the current system, with $60 \%$ of the votes, while if he gambles on pleasing new constituents he runs a $10 \%$ risk of defeat.

92. See Whitcomb v. Chavis, 403 U.S. 124, 168-69 (1971) (separate opinion of Harlan, J.); A. DowNs, supra note 70 , at 244 (probability of a given individual's vote being decisive virtually infinitesimal).

93. See A. Downs, supra note 70, at 267-71; R. Dowse \& J. Hughes, Political Socrology 301 02 (1972); C. Pateman, Participation and Democratic Theory 42 (1970). This is not to say, however, that civic obligation is the self-conscious reason most voters would give to explain why they vote.

A final point deserving mention is that visible rewards of political participation powerfully bolster the socialization process that encourages individuals to exert time and money to vote. Mainstream citizens regularly see their preferred candidates elected. Each mainstream citizen feels fully repre- 
ything, lottery voting increases and celebrates that sense of individual responsibility by guaranteeing that one individual's registered preference will "count" in the strong sense.

\section{B. Lottery Voting Compared to Cumulative Voting}

Although lottery voting and cumulative voting both promote proportional representation, they do so in different ways. A careful investigation of these differences further illuminates the implications of lottery voting.

\section{Proportional Representation and Cross-Sectionalism}

Lottery voting has a number of advantages over cumulative voting. In the absence of a strong party system where, for instance, voters vote for parties themselves and not individual candidates, cumulative voting cannot guarantee minorities proportional representation in the legislature. ${ }^{94}$ Lottery voting can ensure proportional representation without a strong party system. Moreover, if a state is divided into many small multi-member districts, the composition of the state assembly selected by cumulative voting might fall far short of proportional representation. ${ }^{95}$ Indeed, unless the state is treated as one large multi-member district, there is always an incentive to gerrymander because there are always alternative district maps that change the number of seats a party could expect to receive. This is so because, like the current system, cumulative voting fails to focus sharply on the marginal voter and his individual moral responsibility. ${ }^{96}$

\section{Issue-Oriented Politics and Local Representation}

Lottery voting would encourage minor parties to emphasize issues, whereas cumulative voting may lead to the growth of fringe parties energized only by the charisma of established party chieftains. Under cumula-

sented and believes that his individual participation has been rewarded in some sense, even though his individual vote in no way determined the outcome. The success of one's preferred candidate leads to the feeling that one's vote has in some vague sense "counted," and encourages the individual to vote in the future. Because the first-choice candidates of minority voters rarely win, the participation of individual minority voters is never similarly rewarded, and minority voters may give up on the electoral process. Lottery voting, however, ensures that some first-choice minority candidates will win, and would thus tend to increase minority participation in voting. See Latimer, Black Political Representation in Southern Cities, 15 URB. AfF. Q. 65, 80-81 (1979) (black voter participation increases when blacks no longer submerged in at-large elections).

94. In the example supra note 52 , if the party miscalculates its strength and runs two candidates who split the vote, or if party supporters fail to follow party instructions slavishly, the party may well be denied proportional representation.

95. See Silva, supra note 38, at 755. Statewide or large-district elections, on the other hand, may well be more expensive for minority parties (because of travel and media costs) than small-district elections. Cf. supra pp. 1296-97 (discussing electoral economies of scale).

96. See supra pp. $1299-1300$. 
tive voting, a minor party can simply run one or two candidates who are guaranteed election if party loyalists "bullet" their votes. ${ }^{97}$ (Thus, cumulative voting, like the current system, promotes the development of an entrenched cadre of professional legislators, and discourages rotation.) In a lottery vote system, by contrast, a party will run a statewide slate of candidates: ${ }^{98}$ A minor party can be quite confident that some of its district candidates will be elected, but it cannot know which ones. It would consequently seek to emphasize the party platform more than the personal appeal of a few party leaders.

Additionally, large multi-member districts-necessary to ensure crosssectionality under cumulative voting-undermine local representation. Lottery voting, in contrast, is compatible with local (single member) districts. ${ }^{99}$ Although a local representative under lottery voting would not necessarily represent a local majority, he would nonetheless be a local citizen. ${ }^{100}$ Furthermore, lottery voting may result in a beneficial change in the perception of outgroups by the local majority. The idea that a black citizen may occasionally be elected as a representative from a predominantly white district would serve as a useful reminder to local whites that they do not constitute the whole community; local blacks, too, are citizens, and as such are entitled to win some of the time.

\section{Theoretical Implications}

Finally and perhaps most important, cumulative voting is not as intuitively or theoretically straightforward-and thus not as heuristically valuable to the polity-as lottery voting. If nothing else, lottery voting is a powerful theoretical paradigm that affords an especially sturdy vantage point from which citizens could view some of the critical implications of, and defects in, the current system of electing legislatures. The very notion of lottery voting acutely focuses attention on the crucial, if controversial, ideas that all votes should count equally in a way that they don't today; that a local majority of fifty-one percent is not entitled to win one hundred percent of the time; and that currently elected representatives often represent not "the people" of their local districts, but rather only a part-the larger part, yes, but not the only part-of the entire commu-

97. See supra note 52 (describing "bulleting").

98. This assumes that a given candidate may not run in more than one district simultaneously. $C f$. infra note 103 (suspending assumption).

99. Both local and proportional representation are important values. The current system achieves the former by sacrificing the latter, while cumulative voting returns the compliment. Lottery voting preserves both local and proportional representation.

100. Indeed, on specifically local issues, even a minority party's assemblyman might often represent a local majority: All citizens of Selma-black and white-may favor increased state aid to the city. 
nity. Lottery voting would thus powerfully affirm to the polity the equality of all voters, not merely of those in the majority. Cumulative voting, in contrast, sends the same implicit message as the current system: After all the votes are added up, the votes of the "losers" should be disregarded and only votes for the "winners" should count. Because cumulative voting lacks the intuitive simplicity of lottery voting, it is more easily manipulable. ${ }^{101}$ Indeed, seemingly minor changes in voting rules could drastically reduce the degree of proportionality in the final result. ${ }^{102}$

\section{The Virtues of Cumulative Voting}

None of this, however, implies that the lottery voting paradigm should leave us indifferent between cumulative voting and the current system. On the contrary, large-district cumulative voting is far closer to the crosssectional ideal that animates lottery voting than is the current system. ${ }^{103}$ Thus, one important conclusion of the lottery voting thought experiment is that this version of cumulative voting is-in principle, and not simply as a matter of policy-much to be preferred over the prevalent mode of electing legislatures. ${ }^{104}$

Indeed, in several respects, cumulative voting may be preferable to lottery voting. Under lottery voting, a small-party legislator would be less likely to be reelected than his major-party colleagues. ${ }^{105}$ This more rapid rotation of office-holding means that minor parties would probably be represented by legislators with less legislative experience, a state of affairs that could disadvantage such parties. ${ }^{108}$ Additionally, cumulative voting

101. The complexity of cumulative voting may also disadvantage the less educated and thus, the less wealthy. See Note, supra note 38, at 155.

102. A change in the rules concerning "bulleting," for example, could transform cumulative voting into "limited voting" or at-large voting-perhaps the most discriminatory system of all. See supra notes 52,59 ; Note, supra note 38 .

103. Indeed, many of the salient differences between lottery voting and cumulative voting would shrink or evaporate if lottery voting were modified by: (1) allowing (or requiring) voters to cast ballots for parties or candidate slates instead of individual candidates, see supra p. 1300; (2) allowing a candidate to run in more than one district, see supra note 98; or (3) using lottery voting in multimember districts, see supra note 1; p. 1301.

104. Cf. J. RAwLs, supra note 17, whose thought experiment of an "original position" behind a "veil of ignorance" is designed to demonstrate how measures to help the worst-off elements of society are justified as a matter of principle.

105. For example, a legislator from a $5 \%$ minority party stands a much lower chance of reelection than one from a $55 \%$ majority party. An additional potential disadvantage of lottery voting's increased rotation is that individual legislators may be less well-known to one another, a state of affairs that could possibly lead to a reduction of the deference and courtesy currently extended to legislative minorities, see infra p. 1304. On the other hand, rotation would dampen the development of a legislative clubbism that tends to sever the government from the people. See supra p. 1298.

106. Indeed, there may even be a temptation under lottery voting for a minority candidate, once elected, to sacrifice the interests of party constituents to broaden his electoral base and increase his prospects for re-election. This is less likely to happen under cumulative voting, where a minority candidate generally need only please those who first voted for him to win re-election. 
enables statewide minority voters to elect directly "their" representative, while lottery voting would achieve proportional representation through a system of "virtual" representation in which voters must sometimes rely on legislators from other districts to represent their interests. ${ }^{102}$ Finally, because cumulative voting has been applied before, ${ }^{108}$ it is of course a more time-tested and politically realistic alternative than lottery voting.

\section{The Practical and Constitutional Limits of LOTTERY VOTING}

\section{A. The Unwisdom of Applying Lottery Voting to the Executive Branch}

Although lottery voting is a workable method for electing legislatures, it should not be used to select all public officials. It is, for example, an impractical way to choose a governor. The law of averages is of no use here; unlike a legislature, one person cannot be cross-sectional. Moreover, the turn-taking that lottery voting effects over time is dangerous when a given individual can significantly damage the polity through his office. If two percent of the people vote for eccentrics, one eccentric among fifty assembly members cannot work serious harm. An eccentric governor, however, could paralyze the state.

\section{B. The Inapplicabilty of Lottery Voting to Issue-Votes}

Lottery voting is an undesirable system for votes on individual bills. On an issue-vote, the losers of a lottery vote could simply resubmit their proposal the next day with the obvious danger of inconsistent results. To try to prevent reconsideration of the proposal would be folly: Sometimes external circumstances change suddenly, and the polity needs to reconsider suggestions previously rejected. Moreover, a ban on reconsideration would be difficult to police: How much must an old proposal be amended in order to qualify as "new"? These problems do not arise in the selection of representatives because their election occurs only at well-defined periodic intervals (e.g., once every two years). ${ }^{109}$ Thus, although a lottery vote can be used to elect a legislature, the legislature itself should use majority voting on bills. ${ }^{110}$

107. See generally J. ELY, supra note 4, at 82-88 (using concept of virtual representation to illustrate when courts should intervene).

108. For example, Illinois' lower house was selected by cumulative voting within three-member districts until 1980. In that year, however, cumulative voting was abandoned in Illinois. See ILL. CoNST. art. IV, $\S 2$. Variants of cumulative voting have also been employed in most Western European nations. See D. RAE, supra note 78 , at 31-46 (citing examples).

109. This argument assumes, of course, that recall is not permitted.

110. The social choice rule used to choose representatives need not be the same rule used by representatives. Jurors, for instance, can be selected by lot even though the jury verdict is usually determined by unanimous vote. 
Although lottery voting would not skew the legislature against discrete minorities (as does the current system), these minorities might of course still be outvoted by a majority in the legislature itself. Nevertheless, lottery voting is far more just to minorities than the pure democracy of the direct initiative. Because of the structure of legislatures, minorities command more respect from majorities in a legislature than in the polity at large. ${ }^{111}$ Perhaps we cannot force white voters to listen to blacks in their neighborhoods, but black legislators can interact with and influence their white colleagues. If full integration of schools, churches and neighborhoods is too intrusive, at least we can avail ourselves of the advantages of specialization of labor by integrating legislatures in the hopes of procuring more just and balanced legislation. ${ }^{112}$

Thus, Government by Initiative is cross-sectional, but not truly deliberative. Government by Legislature (as legislatures are currently composed) is deliberative but not truly cross-sectional. Government by a FootnoteFour Judiciary is neither fully cross-sectional (since minorities need not be proportionately represented on the bench) nor fully deliberative (since there are severe constraints on the ability of the judge to receive relevant policy information). ${ }^{113} \mathrm{~A}$ legislature selected by a lottery vote can be both cross-sectional and deliberative. ${ }^{114}$

\section{G. The Danger of Pure Lottery}

There is a risk that lottery voting could degenerate into a pure (Athenian) lottery with each voter voting for himself in the hopes of "winning" the perquisites of high office ("the Prize"). It might therefore be necessary to put into the twirling basket only ballots cast for candidates receiving more than, say, one percent of the total vote. ${ }^{115}$

111. The transaction costs of coalition-building and log-rolling for many minority groups are much lower in the legislature than in the polity at large. See Black, National Lawnaking By Initiatize? Let's Think Twice, 8 Hum. RTs., Fall 1979, at 28; Note, A Madisonian Interpretation of the Equal Protection Doctrine, 91 Yale L.J. 1403 (1982).

112. See supra p. 1286. Lottery voting thus helps soften the stunning irony that legislators may not act with invidious purpose to discriminate against minorities, Washington v. Davis, 426 U.S. 229 (1976), while voters motivated by discriminatory intent regularly succeed in electing virtually allwhite legislatures.

113. See supra p. 1285.

114. The etymology of the word "parliament"-a synonym for legislature-illustrates the centrality of legislative dialogue and deliberation: Derived from the French "parler," to talk, a parliament is a talking body. The legislature is thus legitimated not so much by its expertise, see supra note 89 , as by its democratic character and by the dialogue and deliberation that it occasions. $C f$. Fiss, supra note 12, at 13, 38 (arguing that dialogue, independence, and competence legitimate the judiciary). The democracy, dialogue, and deliberation of the legislature find strong parallels in jury theory.

115. The goal here, however, is not to disenfranchise or stifle minority-party voters or eccentrics, but to eliminate from consideration those "candidates" who are "running" for office for reasons that are venal and therefore not articulable to fellow citizens. Currently, candidates must often demonstrate bona fide candidacy in order to qualify for ballot placement or matching funds. These rules typically 


\section{The Constitutionality of Lottery Voting}

Although critics might raise several obvious constitutional objections to lottery voting, these objections lack merit. Lottery voting not only satisfies but celebrates constitutional norms of republican government and equal protection.

\section{Republican Government}

If lottery voting were used to elect state legislatures, the system might be challenged as violative of Article IV's guarantee that every state have "a republican form. of government."118 Such a challenge clearly should fail. Lottery voting produces a legislature that combines the crosssectionalism of the direct initiative with the deliberative character of current legislatures, and is superior to both, ${ }_{i}^{117}$ if both the current legislative electoral system and the direct initiative system satisfy the guarantee clause, so should lottery voting a fortiori. Indeed, lottery voting would create a legislature that would be far truer than current legislatures to the framers' twin goals that a legislature both reflect and refine the views of the polity. ${ }^{118}$ Although lottery voting has never been used before, we must be careful not to confuse the familiar with the constitutionally necessary. 119

Similar arguments support the constitutionality of lottery voting to elect U.S. Representatives or Senators. The relevant constitutional provisions impose no express requirement of majority rule ${ }^{\mathbf{1 2 0}}$ and at least one court has refused to infer such a requirement. ${ }^{121}$ That refusal seems especially

require a candidate to garner a minimum number of votes or receive the nomination of a recognized political party. See, e.g., Presidential Election Campaign Fund Act, 26 U.S.C. $\$ \S ~ 9001-9012$ (1976); Presidential Primary Matching Payment Account Act, 26 U.S.C. $\$ \S 9031-9042$ (1976).

116. U.S. ConsT. art. IV, $\S 4$ ("The United States shall guarantee to every State in this Union a Republican Form of Government").

117. See supra p. 1304.

118. See supra notes 35,82 . The implications of lottery voting are in many respects strikingly harmonious with the republican ideology of the revolutionary period. See supra notes $62,73,82,83$, 87, 88.

119. The history of the direct initiative is instructive on this point. Now viewed by many as a hallmark of modern democracy, the direct initiative was once attacked as repugnant to "republican government." Compare Pacific States Tel. \& Tel. Co. v. Oregon, 223 U.S. 118 (1912) (initiative and referendum challenged as violative of republican government) with Baker v. Carr, 369 U.S. 186, 259 (1962) (Clark, J., concurring) (absence of initiative and referendum rendered malapportionment unconstitutional).

120. See U.S. Const. art. I, \& 4 ("The Times, Places and Manner of holding Elections for Senators and Representatives, shall be prescribed in each State by the Legislature thereof; but Congress may at any time by Law make or alter such Regulations, except as to the Place of chusing Senators."); id. amend. XVII ("The Senate of the United States shall be composed of two Senators from each State, elected by the people thereof . . . .").

121. Phillips v. Rockefeller, 435 F.2d 976 (2d Cir. 1971) (upholding New York's plurality vote rule for U.S. Senate). 
sound since other sections of the Constitution do require majority votes; ${ }^{122}$ when the framers wanted to impose such a requirement, they did so explicitly.

\section{Equal Protection}

The Fourteenth Amendment's guarantee of equal protection of the laws applies by its terms to states ${ }^{123}$ and has been held to apply to the federal government as a component of the Fifth Amendment's due process clause. $^{124}$ An argument could be made that, by introducing ${ }^{125}$ chance into the electoral process, lottery voting is arbitrary, anti-rational, and therefore violative of equal protection principles. ${ }^{126}$ But lottery systems are not always abdications to irrationality, and can instead be powerful weapons to reaffirm our commitment to human equality ${ }^{127} \mathrm{Few}$, for example, would argue that majority rule is anti-rational or arbitrary merely because a bare majority can make the "wrong" choice. Lottery voting merely extends the apparent equality of voters under majority rule-which does not fully count minority voters - to all electors. In so doing, it champions the true spirit of the equal protection clause: the protection of "minorities from the tyranny of majority rule."128

The equal protection argument against lottery voting also focuses on the wrong level of the electoral process. Although the election vel non of any individual candidate depends on chance under lottery voting, the law of averages ensures that the overall complexion of the legislature will be

122. U.S. CoNsT. art. II, $\S 1$ (electoral college); id. amend. XII (same).

123. Id. amend. XIV $\S 1$ ("[N]or shall any State . . . deny to any person within its jurisdiction the equal protection of the laws.").

124. See Bolling v. Sharpe, 347 U.S. 497 (1954).

125. Fortune has always played an important role in politics. Indeed, one of the founders of modern political science describes virlu ("virtue") and forluna ("chance") as the two dominant forces in political affairs. N. Machievelli, The Prince ch. 1 (Musa ed. 1964). Even today, the outcome of an election may easily turn on such stochastic elements as the weather on election day or the exact hour of the vote. Nevertheless, lottery voting enshrines the presence of randomness in ways that the current system does not.

126. Case law, however, supports the constitutionality of electoral systems employing chance in pursuit of equality and cross-sectionalism. See Cambell v. Board of Educ., 310 F. Supp. 94 (E.D.N.Y. 1970), which upheld the use of random selection of surplus ballots in an election based on the "Hare" system discussed supra note 38: "The fact that an element of chance is incorporated into a method of election is not necessarily violative of the Equal Protection Clause... . There can be no denial of equal protection when all share an equal opportunity to have their votes count in an election." Id. at 103-04 (emphasis added). See supra note 70 (lottery voting ensures equality of voting opportunity). See also Moore v. Election Comm'rs, 309 Mass. 303, 333-34, 35 N.E.2d 222, 240 (1941) ("[A] method of counting [votes] is not necessarily vitiated by the possibility of an element of chance in its application to some situations that may arise if, in general, equality among all qualified voters is maintained.").

127. See Greely, supra note 17, at 141; see also J. ELY, supra note 4, at 137 (suggesting constitutionality of lottery-based allocative choices). Plato, justly celebrated for his commitment to reason, also championed the lottery. See supra note 87.

128. Greely, supra note 17 , at 138-39. 
anything but random or arbitrary. Because the power to legislate vests in the legislative body as a whole, we should view the elections of individual legislators as subsidiary to our overall, and eminently rational, plan to create a cross-sectional legislative body. Current district systems are therefore precisely backwards. By focusing on the election of individual legislators in individual districts, these systems ignore cumulative effects on the legislative body as a whole; inexplicably, the overall complexion of the legislature is ultimately molded by an inherently arbitrary district map. ${ }^{128}$

Finally, the use of the lot to select jury venires dramatically undercuts any equal protection argument against lottery voting. Given that the lottery is now a preferred device in administering our system of formal justice, ${ }^{130}$ its use as one part of our electoral system would seem to be constitutional a fortiori. ${ }^{131}$

129. See supra pp. 1293-96.

130. See supra p. 1287-89.

131. To the extent that the jury is functionally and institutionally different from the legislature-that is, to the extent that juries are not "little parliaments," see supra note 18, it would seem that cross-sectionalism is more important for legislatures. First, restrictions on cross-sectionalism are more excusable in light of the rule of unanimity (or near unanimity) for criminal juries. A tiny cluster of "extreme" jurors has absolute veto power over convictions and can force the state to undergo considerable expense in retrying (or releasing) the defendant. Since legislatures are run by majority rule, proportionate representation of all significant minority groups in the legislature does not raise the spectre of impasse created by a majority held hostage. Second, the reduction of diversity of viewpoints on the jury through peremptory challenge may serve to reduce improper, but unprovable, bias. Personal predispositions are anathema to the ideal of impartiality in judicial proceedings, but are often the very stuff of politics. Third, because the jury is much smaller than the ordinary legislature, see Williams v. Florida, 399 U.S. 78 (1970) (upholding Florida six-man jury system), the law of averages cannot guarantee the proportional representation of interests to the same degree that it does in the legislature. See supra note 41.

Additionally, a jury gives no reasons for its verdict and typically sits for only one case. Random selection therefore increases the prospect of inconsistent adjudications, a prospect in tension with the rule of law, equal protection, and formal justice. These objections do not apply to a legislature selected by lottery voting. Legislatures sit for extended stints and write laws of general applicability to be applied alike in all like cases. The law of averages, when combined with the use of majority rule in the legislature, will assure that the legislative "verdict" on a given issue-determined by the median legislator-will not shift dramatically when a new legislature is chosen. Moreover, because lottery voting uses the ballot box as well as the draw, legislators will be more accountable than randomlyselected jurors. Lottery voting contemplates an assembly in which legislators are typically leaders of the diverse groups in the polity. Lottery voting thus offers the cross-sectionalism of the random jury without sacrificing the deliberateness, stature, and wisdom of the ideal "blue-ribbon" jury. See supra p. 1297.

Finally, the jury as an institution simply cannot securely protect us against bad laws in the way that a more cross-sectional legislature can. Juries sit only in a fraction of all civil and criminal cases, and have no role whatsoever in administrative proceedings. And even in the few cases jurors hear, they are expressly told that they may only find the facts: They are not supposed to make policy but must follow the law as it is laid down by the judge. But see Jury Hearings, supra note 18, at 256 (remarks of Irving Kaufman) (jury is law-shaper). 


\section{CoNCLUSION}

Enormous logistical, political, and psychological questions surrounding lottery voting remain to be explored. ${ }^{\mathbf{1 3 2}}$ One Note cannot hope to address all these issues; this Note is meant only as a first word on a subject that deserves the attention of legal theorists and political philosophers. After deep consideration, many may reject lottery voting as a defective or unworkable system in practice. But like the microeconomist's model of an economy without transaction costs, or the philosopher's model of the perfectly just republic, the lottery voting model can also serve as a potent heuristic device. By challenging our most deeply held and often unreflective assumptions about representative democracy and republicanism, the lottery voting thought experiment can deepen our understanding of political and constitutional questions of the first order, and can suggest new approaches to age-old problems of minority rights in a majoritarian society.

132. For example: How could we detect and prevent mechanical manipulation of the lottery? Equally important, how could we prevent the appearance of manipulation? How might the appearance of arbitrariness in individual elections affect citizens' and candidates' perceptions of government? Would such a visible use of the lottery fit the nomos of modern America, where few share the ancient Greek's view of fate-a view which may have more easily reconciled the ancients to myriad and visible uses of lotteries? 